\title{
DEVELOPMENT OF CELLULOSE NANOFIBRE (CNF) DERIVED FROM KENAF BAST FIBRE AND IT'S POTENTIAL IN ENZYME IMMOBILIZATION SUPPORT
}

\author{
(Penghasilan Nano-Gentian Selulosa (CNF) diperolehi daripada Gentian Kulit Kenaf dan \\ Potensinya sebagai Penyokong Pemegunan Enzim) \\ Safwan Sulaiman ${ }^{1}$, Mohd Noriznan Mokhtar $^{1 *}$, Mohd Nazli Naim ${ }^{1}$, Azhari Samsu Baharuddin ${ }^{1}$, \\ Mohamad Amran Mohd Salleh ${ }^{2}$, Alawi Sulaiman ${ }^{3}$ \\ ${ }^{I}$ Department of Process and Food Engineering \\ ${ }^{2}$ Department of Chemical and Environmental Engineering \\ Faculty of Engineering, \\ Universiti Putra Malaysia, 43400 Serdang, Selangor, Malaysia \\ ${ }^{3}$ Faculty of Plantation and Agrotechnology, \\ Universiti Teknologi MARA, 40450 Shah Alam, Selangor, Malaysia \\ *Corresponding author: noriznan@upm.edu.my
}

Received: 24 February 2015; Accepted: 27 October 2015

\begin{abstract}
This research mainly focuses on developing a natural cellulose nanofibre (CNF) from kenaf bast fibre and its potential for enzyme immobilization support. CNF was isolated by using a combination between chemical and mechanical treatments such as alkaline process and high-intensity ultrasonication process to increase the efficiency of hemicellulose and lignin removal, and to reduce its size into nano-order. The morphological study was carried out by using scanning electron microscope (SEM), indicating most of CNF diameter in range of 50-90 nm was obtained. The result of chemical analysis shows that cellulose content of raw bast fibre, bleached pulp fibre and $\mathrm{CNF}$ are $66.4 \%, 83.7 \%$ and $90.0 \%$, respectively. By decreasing the size of cellulose fibre, it increases the number of $(\mathrm{O}-\mathrm{H})$ group on the surface that plays as important role in enzyme immobilization. Covalent immobilization of cyclodextrin glucanotransferase (CGTase) onto CNF support resulted in about $95.0 \%$ of protein loading with $69.48 \%$ of enzyme activity, indicating high immobilization yield of enzyme. The enzymatic reaction of immobilized CGTase was able to produce more than $40 \%$ yield of $\alpha$-CD. Reusability profile of immobilized CGTase resulted in more than $60 \%$ of retained activity up to 7 cycles. Therefore, the CNF is highly potential to be applied as enzyme immobilization support.
\end{abstract}

Keywords: cellulose nanofibre (CNF), kenaf, enzyme immobilization; cyclodextrin glucanotransferase (CGTase), chemical and mechanical treatments

\footnotetext{
Abstrak

Kajian ini memberi tumpuan terutamanya kepada penghasilan nano-gentian selulosa (CNF) semulajadi daripada gentian lapisan kulit kenaf dan potensinya sebagai penyokong pemegunan enzim. CNF dihasilkan dengan menggunakan gabungan antara rawatan kimia dan mekanikal seperti proses alkali dan proses ultrasonikasi berintensiti tinggi untuk meningkatkan kadar kecekapan penyingkiran hemiselulosa dan lignin, dan pengurangan saiz kepada nano. Kajian morfologi menggunakan mikroskop imbasan elektron (SEM), menunjukkan sebahagian besar daripada saiz diameter CNF diperolehi dalam julat 50-90 nm. Hasil kajian analisis kimia menunjukkan bahawa kandungan selulosa daripada gentian mentah, gentian pulpa dan CNF masingmasingnya adalah $66.4 \%, 83.7 \%$ dan $90.0 \%$. Dengan mengurangkan saiz diameter gentian selulosa, ia meningkatkan bilangan kumpulan $(\mathrm{O}-\mathrm{H})$ di permukaan sokongan yang mana memainkan peranan yang penting dalam pemegunan enzim. Pemegunan
} 


\section{Safwan et al: DEVELOPMENT OF CELLULOSE NANOFIBRE (CNF) DERIVED FROM KENAF BAST FIBRE AND IT'S POTENTIAL IN ENZYME IMMOBILIZATION SUPPORT}

Siklodektrin Glukanotransferase (CGTase) secara kovalen pada CNF menunjukkan kira-kira 95.0 \% muatan protein dengan $69.48 \%$ aktiviti enzim, menunjukkan pemegunan enzim yang tinggi terhasil. Tindak balas berenzim CGTase terpegun juga mampu menghasilkan lebih daripada $40 \%$ pengeluaran $\alpha$-CD. Kitaran kebolehulangan enzim terpegun menunjukkan lebih daripada $60 \%$ daripada aktivitinya dapat dikekalkan selama 7 kitaran. Oleh itu, CNF sangat berpotensi untuk digunakan sebagai penyokong pemegunan enzim.

Kata kunci: gentian-nano selulosa (CNF), kenaf, pemegunan enzim, siklodektrin glukanotransferase (CGTase), rawatan kimia dan mekanikal

\section{Introduction}

Nowadays, billions of tons of natural fibre around the world are considered abundant, inexpensive and readily available. Thus, it becomes more interesting to deal with green environment, energy demand, and financial problems. Kenaf (Hibiscus cannabinus L.) is one of the feasible resources of cellulose with economic and ecological advantages. Kenaf consists of two types of fibre, bast and core fibre. Bast refers to outer layer of plant fibre (30\% of dry weight), meanwhile core represents the inner layer of fibre (70\% of dry weight). Bast fibre has been reported possess an excellent mechanical characteristic, which can be an excellent support for enzyme immobilization, as well as alternative to current used of polymer-grafting material support [1]. Bast fibre is one of non-wood lignocellulosic fibres comprises of three major components such as lignin, hemicellulose and cellulose [2]. In fact, cell walls of lignocellulosic fibres consist of basic structural, called as microfibrils. As a result, cellulose microfibrils can actually be considered to be nanofibers, since the definition of a nanofiber is a size $<100 \mathrm{~nm}$ in one dimension [3]. Cellulose is defined as a linear polymer that consists of both crystalline and amorphous region, while hemicellulose and lignin display a complete amorphous structure [4]. Cellulose chain was bound together by hydrogen bonding, whereas lignin and hemicellulose form a matrix surrounding the CNF. Removal of these matrix by top-down approach techniques (chemical-mechanical treatment) is essential to obtain CNF, as well as to improve the surface morphology for enzyme immobilization [5].

The use of CNF in enzyme immobilization is not only to enhance the performance of enzymatic synthesis, but also to minimize the loss of enzyme activity caused by immobilization due to the presence of large surface area per volume ratio [6]. Large surface area also provides a high number of surface functional group especially $(\mathrm{O}-\mathrm{H})$ group on the surface of CNF, which increase the number of the interaction of enzyme onto the CNF support [7]. Covalent interaction is the most stable interaction of enzyme molecules to the support; it can minimize the enzyme leakage from its support into the reaction medium compared to other immobilization techniques [8]. The objective of this work is to study the potential application of CNF from kenaf bast fibre in enzyme immobilization via covalent binding.

\section{Raw material and chemicals}

\section{Materials and Methods}

Kenaf raw bast fibre was a gift from Lembaga Kenaf dan Tembakau Negara (LKTN), Malaysia. All chemicals are technical grade such as sodium hydroxide $(\mathrm{NaOH})$, sodium chlorite $\left(\mathrm{NaClO}_{2}\right)$, acetic acid $\left(\mathrm{CH}_{3} \mathrm{COOH}\right)$, aqueous hydrogen peroxide $\left(\mathrm{H}_{2} \mathrm{O}_{2}\right)$, anthraquinone (AQ), Bradford reagent (coomasive blue), glutaraldehyde (GA), 1,12diaminododecane and bovine serum albumin (BSA) (Merck Chemicals and R\&M Chemicals, Malaysia). Cyclodextrin glucanotransferase from B. macerans (CGTase, EC 2.4.1.19) with activity of $600 \mathrm{U} / \mathrm{ml}$ was purchased from Amano Enzyme Inc., Japan. Water soluble potato starch was purchased from Sigma, Malaysia.

\section{Isolation of CNF support}

The isolation process of CNF consists of several steps of alkaline process and high-intensity ultrasonication. Kenaf bast fibre was retted by using water and then it was oven-dried overnight. Kenaf bast fibre was then cut into shorter, about $1-2 \mathrm{~cm}$ in length. About $20 \mathrm{~g}$ of short bast fibre was heated in aqueous solution containing of $15 \mathrm{wt} \%$ of $\mathrm{NaOH}$ and $0.1 \mathrm{wt} \%$ of $\mathrm{AQ}$, using non-stirred pressure vessel (MOC: SS316, Equipment no: 2311, AMAR Equipments PVT. LTD., Mumbai, India), and the process was called as delignification process. The ratio of fibre to liquid was 1:9 and the process was carried out at $180{ }^{\circ} \mathrm{C}(40 \pm 3$ bar $)$ for $30 \mathrm{~min}$. AQ was added in the solution to increase the delignification rate, as well as to preserve the fibres from alkaline degradation [9]. In fact, delignification process is mainly to remove the lignin content in the fibre. The obtained pulp was rinsed using distilled water several times to remove any residual chemical from it. Bleaching process was performed to remove 
the residual lignin and hemicellulose, which it involved with three stages of different chemical processes (e.g. $\mathrm{NaClO}_{2}, \mathrm{CH}_{3} \mathrm{COOH}, \mathrm{NaOH}$, and $\mathrm{H}_{2} \mathrm{O}_{2}$ ), according to method disclosed by Jonoobi et al. [10]. After a series of bleaching process, bleached pulp fibre was filtered and rinsed with distilled water until it became neutralized $\mathrm{pH}$. The process was repeated five times until the fibre became white, and kept in a water-swollen condition. In preparation of mechanical treatment, the bleached pulp fibre was soaked in distilled water and sonicated by using high-intensity ultrasonic dismembrator (FB705, Fisher Scientific (M) Sdn. Bhd., Malaysia) at $20 \mathrm{kHz}$ of operating frequency, which equipped with $12.7 \mathrm{~mm}$ in diameter size of cylindrical titanium alloy probe. The subsequent ultrasonication was conducted for $30 \mathrm{~min}$ to isolate CNF from bleached pulp fibre. The ultrasonic treatment was carried out in an ice/water bath. Ice was maintained throughout the ultrasonication process to avoid overheating [11].

\section{Functionalized support via chemical coupling reaction}

CNF suspension was freeze-dried. Dried CNF support, about $1 \mathrm{~g}$ was coupled with $1 \mathrm{~g}$ of 1,12-dodecanediamine in $50 \mathrm{ml}$ of methanol containing $5 \mathrm{~g}$ sodium methoxide in a round bottom flask. The reaction mixture was refluxed for 6 hours in a water bath at $80^{\circ} \mathrm{C}$. Then, it was filtered after cooling and washed with distilled water several times to remove any excess chemicals. The $\mathrm{CNF}-1,12$-dodecanediamine derivative was stirred in $40 \mathrm{ml}$ of $0.1 \mathrm{M}$ potassium phosphate buffer ( $\mathrm{pH} 8.0)$, containing $2.5 \%$ (v/v) of GA at $25^{\circ} \mathrm{C}$ for 2 hours. The $\mathrm{CNF}-1,12$-dodecanediamine-GA derivative was filtered and washed with the same phosphate buffer to remove the excess GA.

\section{Covalent immobilization of CGTase onto functionalized CNF support}

The functionalized support (CNF-1,12-dodecanediamine-GA derivative) was suspended in $2.5 \mathrm{ml}$ of enzyme solution, containing $227.48 \mathrm{U} / \mathrm{ml}$ CGTase enzyme and $0.05 \mathrm{M}$ potassium phosphate buffer ( $\mathrm{pH}$ 6.0). The mixture was gently stirred overnight at $4^{\circ} \mathrm{C}$. The unbound enzyme was removed by washing with the same phosphate buffer until there is no enzyme activity detected in the filtrates.

\section{Scanning electron microscopy (SEM)}

SEM (S-3400N, Hitachi, Japan) was used to observe the surface morphology of fibre based on the effect of process treatment. The acceleration voltage was set up in range of $5-20 \mathrm{kV}$, and samples were sputter-coated with gold to avoid charging effect during SEM observations. The fibre diameter was measured by using image analyser software. The results were reported as the average values of the data for each set of measurements.

\section{Chemical analysis}

The cellulose, hemicellulose and lignin contents of CNF were determined by using Fibertec ${ }^{\mathrm{TM}} 2010$ Auto Fibre Analysis System (FOSS Analytical AB, Sweden). The analysis was carried out according to its standard procedure based on FOSS manufacturer's manual. Cellulose, hemicellulose and lignin content were determined by using Acid Detergent Fibre (ADF), Neutral Detergent Fibre (NDF) and Acid Detergent Lignin (ADL). The chemical analysis of sample can be calculated by following formula: (a) Hemicellulose $=$ NDF (hemicellulose, cellulose and lignin) ADF (cellulose and lignin); (b) Cellulose = ADF - ADL (lignin); (c) Lignin = ADL [12]

\section{Protein loading determination}

Bradford method is approximately four times more sensitive compared to Lowry assay [13]. Thus, modified Bradford assay was used to determine the amount of protein loaded onto the functionalized CNF [13]. The quantity of immobilized enzyme was measured after the end of the all washing steps at $595 \mathrm{~nm}$. Bovine serum albumin (BSA) was used as a standard protein. The amount of protein content of immobilized enzyme onto support was calculated by using the following formula: amount of protein after immobilization $=($ amount of protein added $)$ (amount of unbound protein) [14].

\section{Enzyme activity assay ( $\alpha$-cyclodextrin production and enzyme reusability)}

The formation of $\alpha$-cyclodextrin $(\alpha-C D)$ from soluble starch was determined as follows: $30 \mathrm{mg}$ of immobilized CGTase-CNF support was incubated at $60^{\circ} \mathrm{C}$ in a shaking water bath with $20 \mathrm{ml} 0.05 \mathrm{M}$ phosphate buffer, pH 6.0 (containing with $5 \mathrm{w} / \mathrm{v} \%$ of water-soluble starch). There were eight samples were incubated for different reaction times (1-8 hours). The enzymatic reaction was stopped by placing each sample in a boiling water bath for $15 \mathrm{~min}$. The supernatant was collected by centrifugation for $10 \mathrm{~min}(10,000 \mathrm{rpm})$ and passed through a Millipore filter 0.22 


\section{Safwan et al: DEVELOPMENT OF CELLULOSE NANOFIBRE (CNF) DERIVED FROM KENAF BAST FIBRE AND IT'S POTENTIAL IN ENZYME IMMOBILIZATION SUPPORT}

$\mu \mathrm{m}$. The reaction product of $\alpha-\mathrm{CD}$ formation was analysed by using Shimadzu HPLC system (Liquid Chromatograph LC-10AT, Diode Array SPD-M10A, and RID 6A), equipped with a Zorbax Carbohydrate column (L: $150 \mathrm{~mm}$, I.D: $4.6 \mathrm{~mm}$, YMC Co. Ltd., Japan) at $30^{\circ} \mathrm{C}$. With injection volume of $20 \mu$, the sample of $\alpha$-CD was eluted isocratically with acetonitrile-water $(75: 25)$ at a flow rate of $1.0 \mathrm{~mL} \mathrm{~min}^{-1}$. To measure CGTase activity, the enzymatic reaction was run for $5 \mathrm{~min}$. One enzyme activity unit (U) was defined as the amount of enzyme that liberates $1 \mu \mathrm{mol} / \mathrm{min}$ of $\alpha$-CD under the assay conditions.

For the reusability analysis, $30 \mathrm{mg}$ of immobilized CGTase-CNF support was incubated with $20 \mathrm{ml}$ of $5 \%(\mathrm{w} / \mathrm{v}$ ) water-soluble starch in phosphate buffer $(0.05 \mathrm{M}, \mathrm{pH} 6.0)$. The reaction process was repeated up to 7 cycles at $60^{\circ} \mathrm{C}$ for every 1 hour. At the end of each reaction, the supernatant was collected by centrifugation $(10,000 \mathrm{rpm})$ for $5 \mathrm{~min}$ and the content of $\alpha$-CD was analysed as described above. Whereas, the precipitate (immobilized CGTase on CNF) was washed with distilled water. Then, it was re-suspended in $20 \mathrm{ml}$ of freshly prepared substrate to start a new cycle. All results reported are the means of at least three separated experiments.

\section{Scanning electron microscopy (SEM) analysis}

\section{Results and Discussion}

The aqueous suspensions of the raw bast fibre, bleached pulp fibre and CNF after chemo-mechanical treatments are shown in Figure 1. After the chemical treatments, raw bast fibre turned from brown colour into yellowish colour as bleached pulp fibre, indicating a significant amount of lignin and hemicellulose were removed [11]. After the ultrasonication process, CNF suspension turned white colour and homogenously dispersed in water, indicating the nano-sized fibre was sufficiently dispersed and converted to the highly viscous suspension [15].

The surface morphological of raw bast fibre, bleached pulp fibre and CNF were visualized by using SEM, which images of these samples are also depicted in Figure 1. This study reveals that the surface structure of treated fibre was improved in term of its smoothness, roughness and diameter size. Figure 1(a) shows raw bast fibre composed of microfibre bundle and its surface was covered with other impurities (e.g. hemicellulose, lignin, pectin and waxy substances). The average diameter size of raw bast fibre is in a range of 30-70 $\mu \mathrm{m}$. After a series of chemical process, raw bast fibre was separated into individual micro-sized cellulose fibre, representing as bleached pulp fibre as shown in Figure 1(b). The average diameter size of bleached pulp fibre was reduced to 5-20 $\mu \mathrm{m}$. The surface of bleached pulp fibre also found smoother than raw bast fibre and it was reported to be composed of strong hydrogen bonding between cellulosic fibril [16]. Thus, removal the impurities such as lignin and hemicellulose by delignification and bleaching processes could reduce the diameter of fibres, as well as disintegrated the single sized into individual micro-sized cellulose fibres. Figure 1(c) represents the SEM of CNF after passing through the ultrasonication process, display as a cellulosic filament like a long entangled classical web structure. CNF support also represents the combination of chemical and mechanical treatments could strip down the individual micro-sized cellulose fibre from bleached pulp into nano-sized cellulose fibre (average diameter size: 50-90 nm). Thus, further study on the optimization of preparation factors (e.g. concentration of the chemical used, treatment process time and output power of ultrasonication process) is important to increase the yield of nano-sized cellulose fibre as well as to reduce its diameter size.

\section{Chemical composition}

Highly cellulose content can be extracted by removal of lignin, hemicellulose and other impurities from raw bast fibre using a series of conventional methods. The changes of chemical composition of raw bast fibre, bleached pulp fibre and CNF were presented in Table 1. Initially, raw bast fibre consisted of around $66.4 \%, 18.0 \%$ and $12.6 \%$ of cellulose, hemicellulose and lignin, respectively. During the delignification and bleaching steps, the cellulose content increased up to $83.7 \%$ from raw bast fibre, whereas hemicellulose and lignin decreased to $10.3 \%$ and 5.1 $\%$, respectively. Thus, these major changes were attributed to the chemicals used that employed in process treatment. $\mathrm{NaOH}, \mathrm{NaClO}_{2}, \mathrm{H}_{2} \mathrm{O}_{2}$ and $\mathrm{CH}_{3} \mathrm{COOH}$ were found efficiently in removing most of lignin and hemicellulose in the fibre [10]. In fact, AQ was added during delignification is to enhance the delignification rate and also to protect the fibers from alkali. Delignification was also carried out under pressure, which contributed to loosen the lignin structure from cellulosic fibre, as well as to increase the degradation rate of lignin in a short period of time. This is because, hemicellulose and lignin formed a matrix surrounding cellulose structure [17]. Removal of hemicellulose and lignin is essential to isolate fibre with high cellulose content. After 
ultrasonication, cellulose content in CNF increased up to $90.0 \%$. Hemicellulose and lignin contents decreased to 6.8 $\%$ and $2.4 \%$ respectively. High-intensity of ultrasonication process was able to increase the cellulose content as well as the diameter size of fibre, due to the vibration of water molecules that encourage the dispersion effect of micro-fibre bundles into individual nano-sized cellulose fibres. Nano-order fibre is not only to attribute the increasing of cellulose content on the surface fibre, but also to provide a large surface area per volume ratio. However, variations of these results are corresponding to the result of morphological structure and size of fibres.

(a)

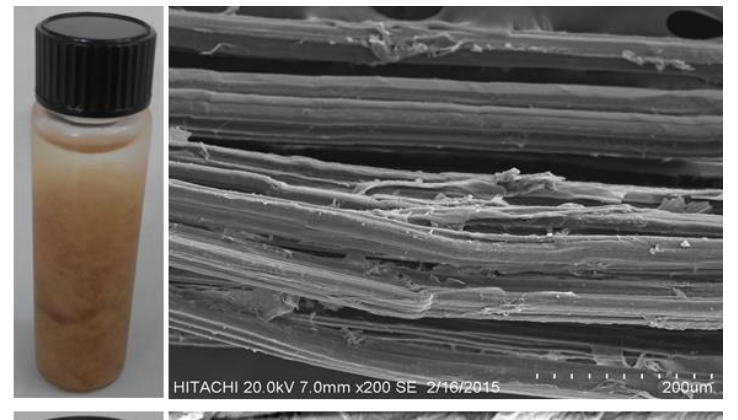

(b)

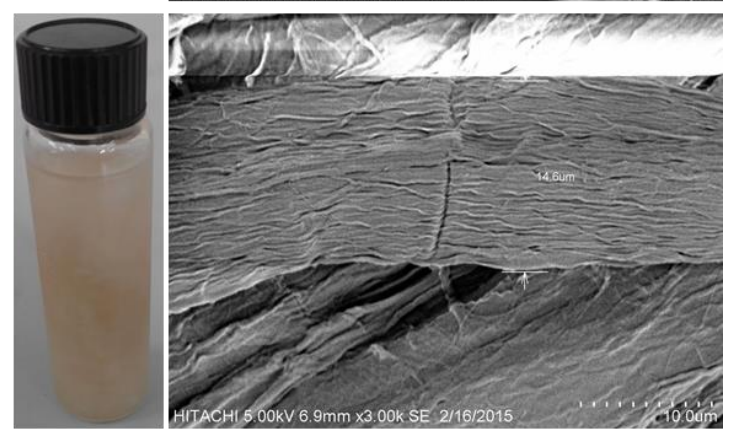

(c)

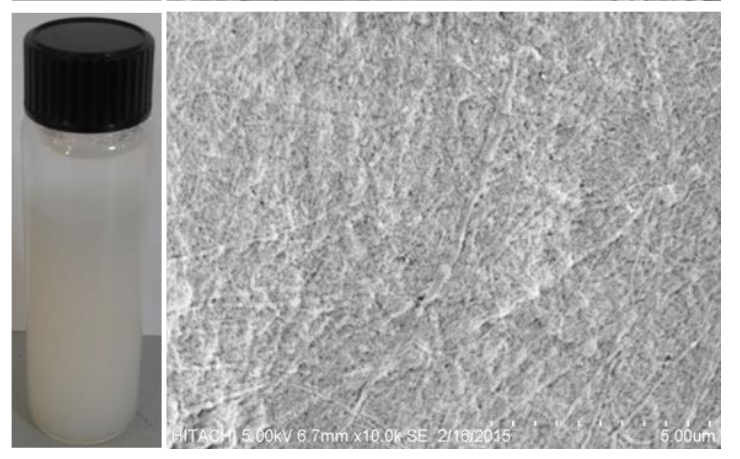

Figure 1. Dispersion states (left) and SEM micrograph (right) of the (a) raw bast fibre (200x), (b) bleached pulp fibre (3000x), (c) CNF (10000x).

Table 1. Chemical composition of kenaf bast fibre (based on dry-weight)

\begin{tabular}{lccccc}
\hline Materials & $\begin{array}{c}\text { Cellulose } \\
(\boldsymbol{\%})\end{array}$ & $\begin{array}{c}\text { Hemicellulose } \\
(\boldsymbol{\%})\end{array}$ & $\begin{array}{c}\text { Lignin } \\
(\mathbf{\%})\end{array}$ & $\begin{array}{c}\text { Extractive } \\
(\boldsymbol{\%})\end{array}$ & $\begin{array}{c}\text { Ash } \\
(\boldsymbol{\%})\end{array}$ \\
\hline Raw bast fibre & $66.4 \pm 1.1$ & $18.0 \pm 1.4$ & $12.6 \pm 0.1$ & $1.7 \pm 0.2$ & $1.4 \pm 0.0$ \\
Bleached pulp fibre & $83.7 \pm 0.3$ & $10.3 \pm 0.9$ & $5.1 \pm 1.2$ & $0.7 \pm 0.3$ & $0.2 \pm 0.1$ \\
CNF & $90.0 \pm 0.3$ & $6.8 \pm 0.4$ & $2.4 \pm 0.2$ & $0.5+0.1$ & $0.0 \pm 0.0$ \\
\hline
\end{tabular}




\section{Safwan et al: DEVELOPMENT OF CELLULOSE NANOFIBRE (CNF) DERIVED FROM KENAF BAST FIBRE AND IT'S POTENTIAL IN ENZYME IMMOBILIZATION SUPPORT}

\section{CGTase immobilization}

In this study, CGTase enzyme was immobilized onto CNF support through covalent binding technique. In detail, covalent binding technique represents the CGTase was covalently immobilized via chemical coupling agents such as 1,12-dodecanediamine (as spacer arm) and GA (as ligand), representing as one of chemical modification techniques. This technique required two mutual reactive functional groups on CNF support surface and enzyme side to perform essential interaction between functional groups [18]. Chemical coupling agents function as specific linkage or anchor from one side of functional group to other side of functional group, representing as [CGTase enzyme-(ligand-spacer arm)-CNF support], which forms a thin layer on surface CNF support. Chemical coupling agents also permit a very strong binding between target enzyme molecules and CNF support at a specific point of reactive group, as promising the accessibility and flexibility of the interaction [18]. Reactive functional group acts as a platform for the interaction between two end-terminals of the chemical coupling, providing the highest chance to create bio-functionalized linkage with the amino group of enzyme [19].

According to the previous research studies, CNF was reported that consists of mainly $(\mathrm{O}-\mathrm{H})$ group on its surface $[9-11,15,20]$. The percentage of immobilization yield is correlated to the interaction of chemical coupling agent onto the surface of CNF. As depicted in Table 2, about $95.0 \%$ of immobilization yield of protein binding with $69.48 \%$ retained enzyme activity were obtained. The results show high percentage of immobilization yield indicates the successfully of interaction between CGTase molecules and CNF support [18]. High percentage of enzyme activity also contributes to the better performance of enzymatic reaction [14, 21-23].

Table 2. CGTase immobilization onto CNF support

\begin{tabular}{cccccccc}
\hline \multicolumn{2}{c}{ Enzyme added } & \multicolumn{2}{c}{ Unbound enzyme } & \multicolumn{2}{c}{ Immobilized enzyme } & \multicolumn{2}{c}{ Immobilization yield } \\
\hline $\begin{array}{c}\text { Protein(Po) } \\
(\mathbf{m g} / \mathbf{g} \\
\text { support) }\end{array}$ & $\begin{array}{c}\text { Activity(A) } \\
(\mathbf{U} / \mathbf{g} \\
\text { support) }\end{array}$ & $\begin{array}{c}\text { Protein } \\
(\mathbf{m g} / \mathbf{g} \\
\text { support) }\end{array}$ & $\begin{array}{c}\text { Activity(U) } \\
(\mathbf{U} / \mathbf{g} \\
\text { support) }\end{array}$ & $\begin{array}{c}\text { Protein(P) } \\
(\mathbf{m g} / \mathbf{g} \\
\text { support) }\end{array}$ & $\begin{array}{c}\text { Activity(I) } \\
(\mathbf{U} / \mathbf{g} \\
\text { support })\end{array}$ & $\begin{array}{c}\text { Binding } \\
(\boldsymbol{\%}) \\
(\mathbf{P} / \mathbf{P o}) \\
\mathbf{x} \mathbf{1 0 0}\end{array}$ & $\begin{array}{c}\text { Activity } \\
(\mathbf{\%}) \\
\mathbf{I}(\mathbf{A}-\mathbf{U}) \mathbf{x} \\
\mathbf{1 0 0}\end{array}$ \\
\hline 30.0 & 568.7 & 1.49 & 119.22 & 28.51 & 312.28 & $95.0 \%$ & $69.48 \%$ \\
\hline
\end{tabular}

The cyclization activity of immobilized CGTase on CNF support was investigated at temperature of $60{ }^{\circ} \mathrm{C}$, in phosphate buffer $(\mathrm{pH}$ 6.0, $0.05 \mathrm{M})$. The enzymatic reaction of immobilized CGTase converted the soluble starch into mainly $\alpha-\mathrm{CD}$ compound. The percentage of $\alpha-\mathrm{CD}$ forming for 1 hour shows drastically increased up to $28 \%$ of production yield and gradually increases up to $48 \%$ after 8 hours of reaction time, as presented in Figure 2 . Substrate limitation and product inhibition probably effected to the enzymatic reaction of CGTase, indicating stationary line when the reaction process time was extended [24]. Fig. 3 shows the reusability of the 7 cycles of repeated batch process of immobilized CGTase. The result indicated that the residual activity has gradually decreased until 7 cycles. The reusability profile of immobilized CGTase describes the residual activity reduced gradually from cycle 1 to cycle 7 , which from $100 \%$ to $66 \%$. After the fifth cycle, the immobilized enzyme shows a little decreasing on its residual activity. Therefore, the immobilized enzyme is able to maintain in a good yield of forming $\alpha-\mathrm{CD}$ even though after 7 cycles. However, both of these results show a good in enzymatic activity either in production of $\alpha-\mathrm{CD}$ or reusability of immobilized CGTase on CNF support through covalent interaction. Thus, the CNF support can be applied as a good support structure for enzyme immobilization. 


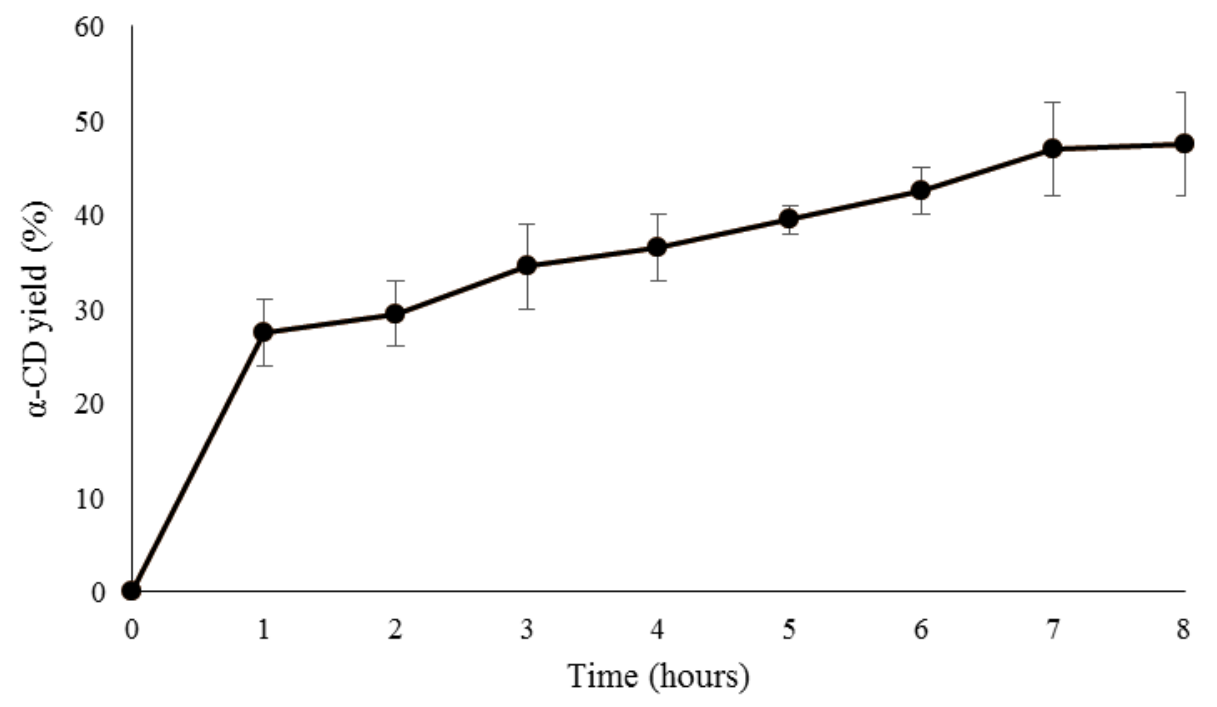

Figure 2. $\alpha$-CD formation by immobilized CGTase. The immobilized CGTase was reacted in a phosphate buffer (0.05 M, pH 6.0), at temperatures $60{ }^{\circ} \mathrm{C}$.

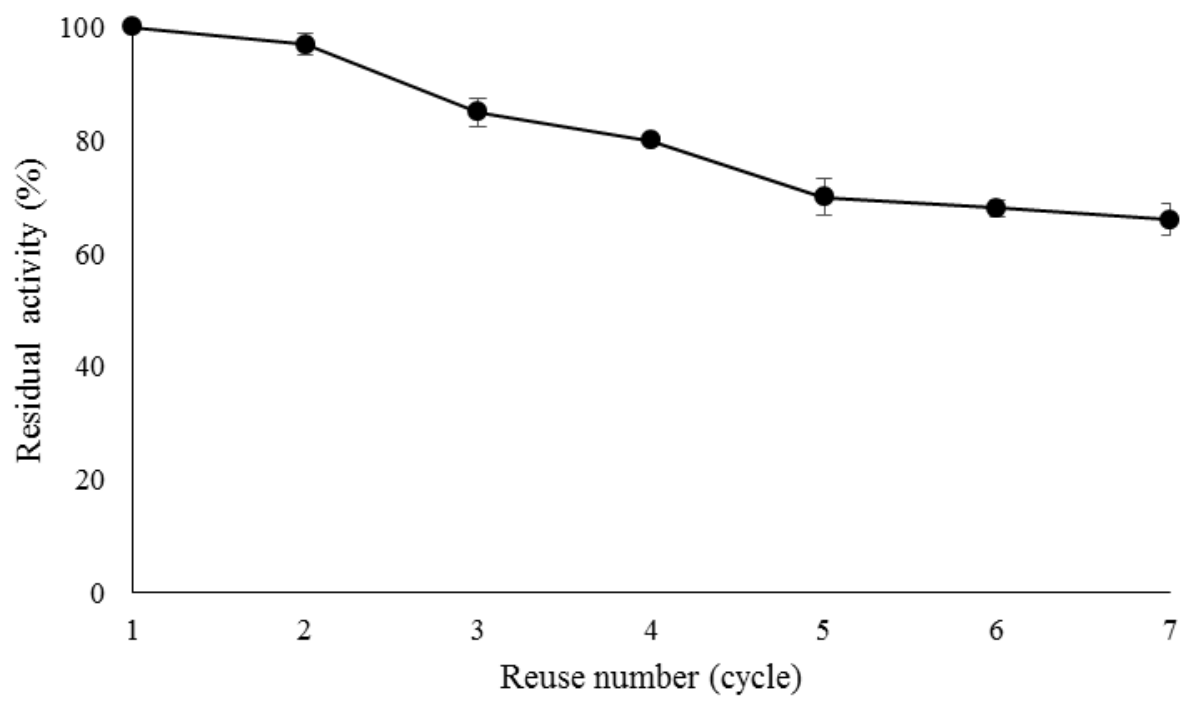

Figure 3. Reusability (repeated batch) of immobilized CGTase. The immobilized CGTase was reacted in a phosphate buffer $(0.05 \mathrm{M}, \mathrm{pH} 6.0)$, at temperatures $60{ }^{\circ} \mathrm{C}$.

\section{Conclusion}

CNF was successfully isolated from kenaf bast fibres by chemical and mechanical treatments. SEM analysis reveals that CNF has different surface morphology and diameter size which reduction of level roughness and size; attributed to each stage of the treatment processes. Chemical analysis of fibre after each chemical process and high-intensity ultrasonication indicated to the increasing in cellulose content by the decreasing of lignin and hemicellulose contents, also indicated the successfully removal of these impurities. Covalent immobilization of CGTase onto CNF support also reveals a good result in the enzyme assay, which promotes a highly $\alpha-\mathrm{CD}$ production and reusability of 


\section{Safwan et al: DEVELOPMENT OF CELLULOSE NANOFIBRE (CNF) DERIVED FROM KENAF BAST FIBRE AND IT'S POTENTIAL IN ENZYME IMMOBILIZATION SUPPORT}

enzyme. Thus, CNF support was potential to be applied in enzyme immobilization due to high exposed surface area as well as to provide high cellulose content (e.g. it increases the number of $(\mathrm{O}-\mathrm{H})$ group on the surface of CNF for the covalent interaction). Developing of nanobiocatalyst system would benefit for both enzyme and nano-sized support, since the enzyme molecule itself is already in the nano-sized.

\section{Acknowledgement}

The authors gratefully acknowledge the financial support by Fundamental Research Grant Scheme (FRGS) from KPM (Grant no. 03-01-14-1426FR) through the Universiti Putra Malaysia and UPM Putra Grant (Grant no. GPIPS/2014/9438711).

\section{References}

1. Faruk, O., Bledzki, A. K., Fink, H.-P. and Sain, M. (2012). Biocomposites reinforced with natural fibers: 20002010. Progess in Polymer Science, 37(11): $1552-1596$.

2. Li, Y., Mai, Y.-W. and Ye, L. (2000). Sisal fibre and its composites: a review of recent developments. Composite Science and Technology, 60(11): 2037 - 2055.

3. Gardner, D. J., Oporto, G. S., Mills, R. and Samir, M. A. S. A. (2008). Adhesion and surface issues in cellulose and nanocellulose. Journal of Adhesion Science and Technology, 22(5-6): 545 - 567.

4. Brinchi, L., Cotana, F., Fortunati, E. and Kenny, J. M. (2013). Production of nanocrystalline cellulose from lignocellulosic biomass: Technology and applications. Carbohydrate Polymer, 94(1): 154 - 169.

5. Zhang, S. (2003). Fabrication of novel biomaterials through molecular self-assembly. Nature Biotechnology, 21(10): $1171-1178$.

6. Kim, J., Grate, J. W. and Wang, P. (2006). Nanostructures for enzyme stabilization. Chemical Engineering Science, 61(3): 1017 - 1026.

7. Kim, J., Grate, J. W. and Wang, P. (2008). Nanobiocatalysis and its potential applications. Trends Biotechnology, 26(11): $639-646$.

8. Cao, L. (2006). Covalent Enzyme Immobilization. In Carrier-bound Immobilized Enzymes. Wiley-VCH Verlag GmbH \& Co. KGaA (pp. 169-316)..

9. Karimi, S., Tahir, P. M., Karimi, A., Dufresne, A. and Abdulkhani, A. (2014). Kenaf bast cellulosic fibers hierarchy: A comprehensive approach from micro to nano. Carbohydrate Polymer, 101: 878 -885.

10. Jonoobi, M., Niska, K. O., Harun, J., Misra, M., Shakeri, A., Misra, M. and Oksman, K. (2009). Chemical composition, crystallinity, and thermal degradation of bleached and unbleached kenaf bast (Hibiscus cannabinus) pulp and nanofibers. BioResources, 4(2): 626 - 639.

11. Chen, W., Yu, H., Liu, Y., Chen, P., Zhang, M. and Hai, Y. (2011). Individualization of cellulose nanofibers from wood using high-intensity ultrasonication combined with chemical pretreatments. Carbohydrate Polymer, 83(4): $1804-1811$.

12. Van Soest, P. J., Robertson, J. B. and Lewis, B. A. (1991). Methods for dietary fiber, neutral detergent fiber, and nonstarch polysaccharides in relation to animal nutrition. Journal of Dairy Science, 74(10): 3583 - 3597.

13. Bradford, M. M. (1976). A rapid and sensitive method for the quantitation of microgram quantities of protein utilizing the principle of protein-dye binding. Analytical Biochemistry, 72(1-2): $248-254$.

14. Abdel-Naby, M. A., Ismail, A.-M. S., Abdel-Fattah, A. M., and Abdel-Fattah, A. F. (1999). Preparation and some properties of immobilized Penicillium funiculosum 258 dextranase. Process Biochemistry, 34(4): 391 398.

15. Chen, W., Yu, H. and Liu, Y. (2011). Preparation of millimeter-long cellulose I nanofibers with diameters of 30-80nm from bamboo fibers. Carbohydrate Polymer, 86(2): $453-461$.

16. Abe, K. and Yano, H. (2009). Comparison of the characteristics of cellulose microfibril aggregates of wood, rice straw and potato tuber. Cellulose, 16(6): 1017 - 1023.

17. Joonobi, M., Harun, J., Tahir, P. M., Zaini, L. H., SaifulAzry, S. and Makinejad, M. D. (2010). Characteristics of nanofibres extracted from kenaf core. BioResources, 5(4): 2556 - 2566.

18. Sulaiman, S., Mokhtar, M. N., Naim, M. N., Baharuddin, A. S. and Sulaiman, A. (2014). A Review: potential usage of cellulose nanofibers (CNF) for enzyme immobilization via covalent interactions. Applied Biochemistry and Biotechnology, 175(4): 1817 - 1842.

19. Redeker, E. S., Ta, D. T., Cortens, D., Billen, B., Guedens, W. and Adriaensens, P. (2013). Protein engineering for directed immobilization. Bioconjugate Chemistry, 24(11): 1761 - 1777. 
20. Chen, W., Yu, H., Liu, Y., Hai, Y., Zhang, M. and Chen, P. (2011). Isolation and characterization of cellulose nanofibers from four plant cellulose fibers using a chemical-ultrasonic process. Cellulose, 18(2): $433-442$.

21. Karim, M. R. and Hashinaga, F. (2002). Preparation and properties of immobilized pummelo limonoid glucosyltransferase. Process Biochemistry, 38(5): 809 - 814.

22. Martín, M. T., Plou, F. J., Alcalde, M. and Ballesteros, A. (2003). Immobilization on Eupergit C of cyclodextrin glucosyltransferase (CGTase) and properties of the immobilized biocatalyst. Journal of Molecular Catalysis B: Enzymatic, 21(4-6): $299-308$.

23. Ivanova, V. (2010). Immobilization of cyclodextrin glucanotransferase from Paenibacillus macerans ATCC 8244 on magnetic carriers and production of cyclodextrins. Biotechnology and Biotechnical Equipment, 24: 516 -528 .

24. Shahrazi, S., Saallah, S., Mokhtar, M. N., Baharuddin, A. S. and Yunos, K. F. M. (2013). Dynamic mathematical modelling of reaction kinetics for cyclodextrins production from different starch sources using Bacillus macerans cyclodextrin glucanotransferase. American Journal of Biochemistry and Biotechnology, 9(2): $195-205$. 